\title{
THE DIFFICULTIES OF INDONESIAN STUDENTS IN LEARNING ENGLISH PLURAL FORM: CONTRASTIVE ANALYSIS
}

\author{
Komang Trisnadewi \\ English Education \\ Institute Hindu Dharma Negeri Denpasar \\ Email: kmgtrisna@yahoo.com
}

\begin{abstract}
A comparative analysis is needed between the two languages or known as contrastive analysis to identify their structural similarities and differences so that the material and methods of teaching will be appropriate. Further than that, this paper is aimed to give a clear understanding about how Indonesian differs from English in the sense of its language features, especially in plural form. It is known that the structure of the plural between English and Indonesian is different although some similarities were found. Indonesian learners will find it difficult to learn plural words because in terms of word formation, English and Indonesian are very different. The formation of plural words in English is through the process of affixation, while in Indonesian, the formation of plural is through reduplication and addition of quantifier and number. It is necessary to give more explanations and exercises to learn the plural of English because with a lot of practice, it is hoped that Indonesian learners will start to get used to the formation of the plurals.
\end{abstract}

Keywords: Contrastive analysis, Plural form

\section{INTRODUCTION}

Human use language to communicate with family and other people. The language that was first learned or known as language acquisition is called the first language (mother tongue). Indonesian people have diverse first languages, such as Balinese, Javanese, Madurese, etc. depending on the environment. The national language, "Bahasa Indonesia", is also spoken as mother tongue by some people, especially for those who live in cities.

Furthermore, learning a language that is not the first language is known as second language learning and foreign languages. In Indonesia, a foreign language that becomes, a compulsory subject is English. Izzan (2008) says that when a child is in the process of learning a new language, he actually faces problems including recognition, hearing, and pronunciation stages. It can be said that learning a foreign language is trying to form and foster new habits that are done consciously. In that process, language learning experience will help the learner.

Izzan (2008) also adds that the progress of learning English for Indonesian is very dependent on the extent of differences and similarities between the language of students and the English language. How far the language of students can influence the learning process of English. The similarities that arise between these languages will certainly have a positive impact on progress in learning the foreign language. While the differences that arise will certainly cause problems in understanding.

Both English and Indonesian have different families. In the beginning, English came from Germanic from Anglo-Frisian dialects which is brought to the British island by German immigrants from some northwestern regions, now called the Netherlands and Germany. Furthermore, English continued to develop and eventually expanded throughout the world, including Indonesia. Whereas Indonesian language comes from Malay language which is complemented by local 
language elements and entered by foreign words (Usman, 1960 in Bawa et al, 1989).

In the process of learning English, students will be given knowledge about English starting from sounds, letters, words, sentences, and until they are able to make paragraphs. In studying words, they are two forms namely single and plural forms. A single word refers to a thing / thing. While the plural word refers to things / objects which number more than one. The explanation is sounds simple, but in fact, students have difficulty in learning the plural English markers. It could be seen in the following errors: many table, two foots, and six matchs.

Indonesian people who study English will certainly encounter difficulties related to sound system, vocabulary, sentence structure, sentence formation, and even social culture. These problems and difficulties need to be examined so they can be overcome. A comparative analysis is needed between the two languages or known as contrastive analysis to identify their structural similarities and differences so that later the material and methods of teaching will be appropriate. Further than that, this paper is also aimed to give a clear understanding about how Indonesian differs from English in the sense of its language features, which focuses on plural form.

\section{THEORITICAL FRAMEWORK Contrastive Analysis}

Tarigan (1989) said that contrastive analysis or more popular abbreviated as anakon is the activity of comparing the structure of mother language or first language (L1) with the language acquired or studied after the mother tongue which is better known as the second language (L2) to identify the differences of the two languages. It was also explained that contrastive analysis consists of four steps, namely:

Compare the structures of L1 and L2

1. Predict learning difficulties

2. Arrange teaching material

3. Prepare and choose how to deliver teaching material.

Tarigan (1992) adds that contrastive analysis should ideally have four steps, as follows:

1. Gather data that shows relevant systems in language attitude.

2. State the realizations of each grammatical category related to contrastive analysis.

3. Supply existing data with other compatible and supporting data.

4. Formulate the contrasts that have been found well by / in step two and step three.

The benefits of contrastive analysis are as follows:

1. Help overcome the difficulties of learners in the L2 learning process.

2. Found the points of difficulty of learners.

3. Make appropriate teaching materials and methods.

\section{DISCUSSIONS}

\section{Contrastive Analysis of Plurals in English and Indonesian nouns \\ The word becomes an}

important element in a sentence even more in a communication. Words are things we learn after learning letters and sounds. According to Kamus Besar Bahasa Indonesia (1996), words are elements of spoken or written language which is a manifestation of the unity of feelings and thoughts that can be used in language. It can be said that by choosing the right words, it will help someone to express their feelings and thoughts correctly as well. English has four major word classes, they are noun, verb, adjective, and adverb. There are two forms of noun, singular and plural. These 
word forms becomes a learning topic that should be mastered so that they can be used properly in spoken and written language.

\section{Plurals of English Nouns}

In English, the formation of plural word is done in the following rules (Azar, 2003: 158):

1. Adds -s to the noun (for most nouns). Example: birds, streets, roses, etc.

2. Adds -es to nouns (for nouns ending in -sh, -ch, -ss, -x). Example: dishes, boxes, classes, etc

3. For nouns ending in $-y$, the addition of the suffix depends on the letter before $-y$. If the letter before $-y$ is a consonant, then the -ies suffix will be added by omitting the letter $-y$. If the letter before-y is a vowel, then for the plural, the suffix is only added -s. Example: toys, babies, etc.

4. For nouns ending in -fe or $-\mathrm{f}$, then the plural will end in -ves. Examples of knife-knives.

5. For nouns ending in -0 , the plural is to add the -s suffix, and some to add -es. Example: tomatoes, zoos, zeroes / zero, etc.

6. There are several nouns that have their own forms for plural. Example: childchildren.

7. The same as the single form. Example: fish, deer, sheep, offspring, and species.

8. Borrowing from other languages. There are several forms of English plural taken from other languages. Example: bacterium-bacteria.

\section{Plurals of Indonesian Nouns}

In expressing the plural meaning, there are several ways that can be done (Arifin and Tasai, 1985), namely:
1. Reduplication, such as: kudakuda, meja-meja, etc

2. Adding quantifier or number, such as: beberapa, semua, dua, sepuluh, etc

3. Adding plural auxiliary words, such as para (para tamu).

In addition, in Indonesian language, there are also some words taken from foreign languages.

1. The plural form is commonly used instead of the singular form

\begin{tabular}{|c|c|c|}
\hline Singular & Plural & Meaning \\
\hline alumnus & alumni & alumni \\
\hline datum & data & data \\
\hline
\end{tabular}

2. The singular is commonly used instead of the plural form

\begin{tabular}{|c|c|c|}
\hline Singular & Plural & Meaning \\
\hline focus & foci & Focus \\
\hline museum & musea & Museum \\
\hline $\begin{array}{c}\text { laboratoriu } \\
\mathrm{m}\end{array}$ & $\begin{array}{c}\text { laboratori } \\
\text { a }\end{array}$ & $\begin{array}{c}\text { Laborator } \\
\mathrm{y}\end{array}$ \\
\hline
\end{tabular}

3. The singular and plural forms are both used with different meanings. The difference can be seen as follows.

\begin{tabular}{|c|c|c|}
\hline Singular & Plural & Meaning \\
\hline Hadir & hadirin & Audience \\
\hline ruh & arwah & Spirit \\
\hline unsur & anasir & Unsure \\
\hline
\end{tabular}

\section{The Comparison of English and} Indonesian Plural

The comparison of plural can be clearly seen through the following example. 


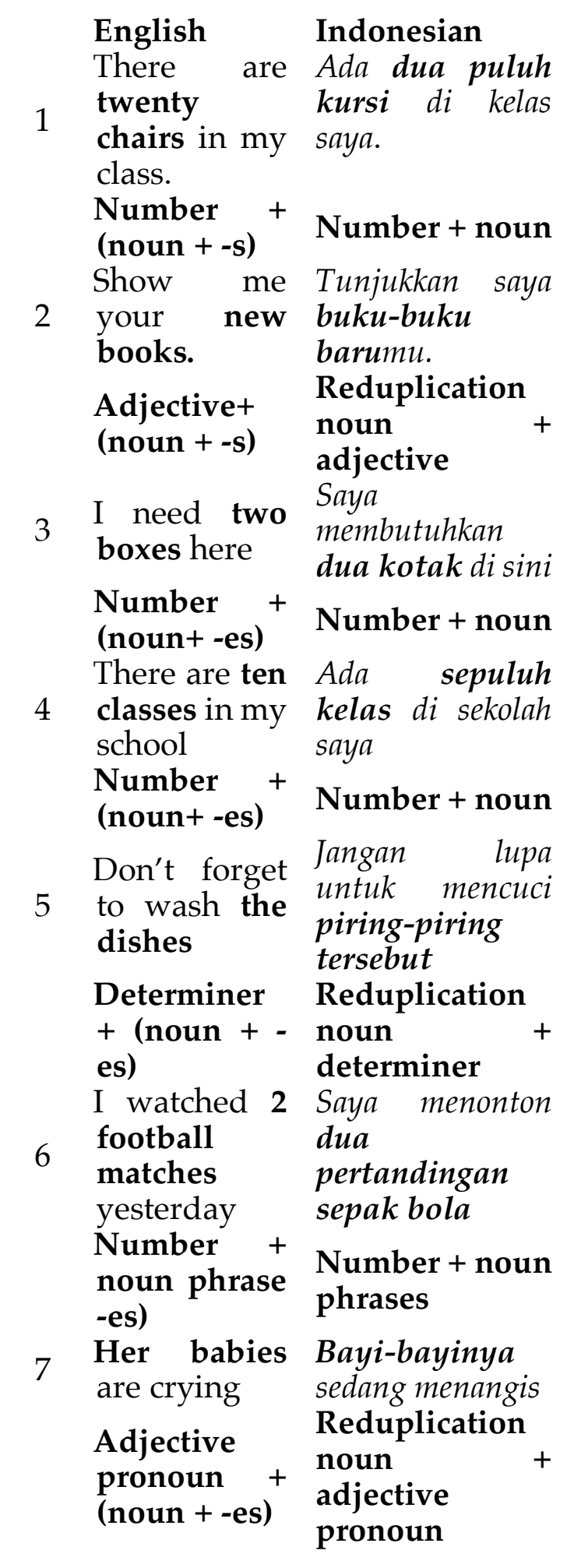
$8 \begin{aligned} & \text { Don't take } \\ & \text { my toys }\end{aligned}$
Adj pronoun Reduplication
$+($ noun $+-s)$ noun + adj pronoun
My mother Ibu saya baru saja
9 just bought membeli dua two knives pisau
Number + (noun + -es) Number + noun
Mother left Ibu meninggalkan
10 two potatoes dua kentang di on the table atas meja

$\underset{\text { (noun }+ \text {-es) }}{\text { Number }}+$ Number + noun

11 pianos does piano yang the studio studio ini have? miliki?

Quantifier + Quantifier + (noun + -s) noun

Tuan John

Mr. John has mempunyai tiga

12 three orang anak children (same with the singular form)

Number +

noun Number + noun sendiri)

I saw two Saya melihat dua

13 fish in your ikan di dalam pond kolammu

Number + Number + noun noun Number t noun

Two bacteria Dua bakteri

14 found in that ditemukan pada child anakitu

Number + Number + noun noun 
The Similarities of English and Indonesian Plurals

\begin{tabular}{|l|l|}
\hline English & Indonesian \\
\hline $\begin{array}{l}\text { I saw two fish } \\
\text { in your pond }\end{array}$ & $\begin{array}{l}\text { Saya melihat dua } \\
\text { ikan di dalam } \\
\text { kolammu }\end{array}$ \\
\hline $\begin{array}{l}\text { I want to have } \\
\text { two deer }\end{array}$ & $\begin{array}{l}\text { Saya ingin } \\
\text { mempunyai dua } \\
\text { rusa }\end{array}$ \\
\hline $\begin{array}{l}\text { There are four } \\
\text { sheep in the } \\
\text { farm }\end{array}$ & $\begin{array}{l}\text { Ada dompat } \\
\text { domba } \\
\text { peternakan }\end{array}$ \\
\hline $\begin{array}{l}\text { Number } \\
+ \text { noun }\end{array}$ & Number +noun \\
\hline
\end{tabular}

Based on the example above, the both Eglish and Indonesian plurals have the same pattern, numerical + noun. The plural form is the same as the singular form of the word, and the plural markers are number, namely two (two) and four

\begin{tabular}{|c|c|c|}
\hline & $\begin{array}{l}\text { English } \\
\text { Plural }\end{array}$ & Indonesian Plural \\
\hline 1 & $\begin{array}{l}\text { There are } \\
\text { twenty } \\
\text { chairs in my } \\
\text { class } \\
\begin{array}{l}\text { Number + } \\
\text { (noun + -s) }\end{array}\end{array}$ & $\begin{array}{l}\text { Ada dua puluh } \\
\text { kursi di kelas saya } \\
\text { Number + noun }\end{array}$ \\
\hline 2 & $\begin{array}{l}\text { Show me } \\
\text { your new } \\
\text { books }\end{array}$ & $\begin{array}{l}\text { Tunjukkan saya } \\
\text { buku-buku barumu } \\
\text { Noun } \\
\text { (Reduplication) + } \\
\text { adjective }\end{array}$ \\
\hline 3 & $\begin{array}{l}\text { I need two } \\
\text { boxes here } \\
\text { Numerical+ } \\
\text { (noun + -es) }\end{array}$ & $\begin{array}{l}\text { Saya } \\
\text { membutuhkan } \\
\text { dua kotak di sini } \\
\text { Number + noun }\end{array}$ \\
\hline 4 & $\begin{array}{l}\text { There are } \\
\text { ten classes } \\
\text { in my } \\
\text { school } \\
\text { Number + } \\
\text { (noun+-es) }\end{array}$ & $\begin{array}{l}\text { Ada sepuluh kelas } \\
\text { di sekolah saya } \\
\text { Number + noun }\end{array}$ \\
\hline
\end{tabular}

(four) words which can be explained as follows.

\begin{tabular}{|l|c|}
\hline (singular) & (plural) \\
\hline Fish & Fish \\
Ikan & Ikan \\
\hline Deer & Deer \\
Rusa & Rusa \\
\hline Sheep & Sheep \\
Domba & Domba \\
\hline
\end{tabular}

Based on the similarities mentioned above, basically Indonesian students will not face difficulties in making plurals of those words, they are fish, deer, sheep, offspring, and species. In practice, Indonesian students must memorize the words and use them more often.

The Differences of English and Indonesian Plurals

The differences of the plurals can be seen in the following sentences.

\begin{tabular}{|c|c|c|}
\hline & $\begin{array}{l}\text { Her babies } \\
\text { are crying } \\
\text { Adjective } \\
\text { pronoun + } \\
\text { (noun }+ \text {-es) }\end{array}$ & $\begin{array}{l}\text { Bayi-bayinya } \\
\text { sedang menangis } \\
\text { Noun } \\
\text { (reduplication) + } \\
\text { adjective pronoun }\end{array}$ \\
\hline & $\begin{array}{l}\text { My father } \\
\text { has two } \\
\text { keys } \\
\text { Number + } \\
\text { (noun + -s) }\end{array}$ & $\begin{array}{l}\begin{array}{l}\text { Ayah saya } \\
\text { mempunyai dua } \\
\text { kunci }\end{array} \\
\text { Number + noun }\end{array}$ \\
\hline 7 & $\begin{array}{l}\begin{array}{l}\text { Don't take } \\
\text { my toys }\end{array} \\
\begin{array}{l}\text { Adjective } \\
\text { pronoun + } \\
\text { (noun }+- \text { s) }\end{array}\end{array}$ & $\begin{array}{l}\text { Jangan ambil } \\
\text { mainan- } \\
\text { mainanku } \\
\text { Noun } \\
\text { (reduplication) + } \\
\text { adjective pronoun }\end{array}$ \\
\hline & $\begin{array}{l}\text { My mother } \\
\text { have bought } \\
\text { two knives } \\
\begin{array}{l}\text { Number + } \\
\text { (noun +-es) }\end{array}\end{array}$ & $\begin{array}{l}\text { Ibu saya baru saja } \\
\text { membeli dua pisau } \\
\text { Number + noun }\end{array}$ \\
\hline
\end{tabular}




\begin{tabular}{|c|c|c|}
\hline & $\begin{array}{l}\text { Mother left } \\
\text { two } \\
\text { potatoes on } \\
\text { the table } \\
\text { Number+ } \\
\text { (noun + -es) }\end{array}$ & $\begin{array}{l}\text { Ibu meninggalkan } \\
\text { dua kentang di atas } \\
\text { meja } \\
\text { Number + noun }\end{array}$ \\
\hline 1 & $\begin{array}{l}\text { How many } \\
\text { pianos does } \\
\text { the studio } \\
\text { have? } \\
\text { Quantifier } \\
+ \text { (noun + - } \\
\text { s) }\end{array}$ & $\begin{array}{l}\text { Berapa banyak } \\
\text { piano yang studio } \\
\text { ini miliki? } \\
\text { Quantifier + noun }\end{array}$ \\
\hline 1 & 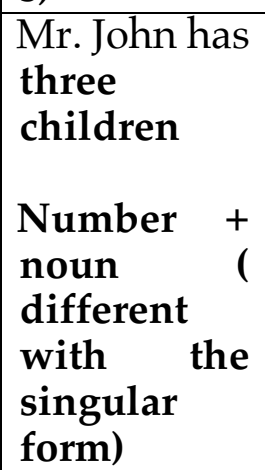 & $\begin{array}{l}\text { Tuan John } \\
\text { mempunyai dua } \\
\text { oranganak } \\
\text { Number + noun }\end{array}$ \\
\hline 1 & $\begin{array}{l}\text { Two } \\
\text { bacteria } \\
\text { found in } \\
\text { that place } \\
\text { Number + } \\
\text { noun } \\
\text { (different } \\
\text { with the } \\
\text { singular } \\
\text { form) }\end{array}$ & $\begin{array}{l}\text { Dua bakteri } \\
\begin{array}{l}\text { ditemukan pada } \\
\text { tempat itu }\end{array} \\
\text { Number + noun }\end{array}$ \\
\hline 1 & $\begin{array}{l}\text { Quantifier } \\
+ \text { (noun +- } \\
\text { s) }\end{array}$ & $\begin{array}{l}\text { Saya memunyai dua } \\
\begin{array}{l}\text { buku untuk } \\
\text { dibagikan }\end{array} \\
\text { Number + noun }\end{array}$ \\
\hline 1 & $\begin{array}{l}\text { I } \\
\text { waited have } \\
\text { days after } \\
\text { days } \\
\text { (Noun }+- \text { s) } \\
+ \\
\text { preposition }\end{array}$ & $\begin{array}{l}\begin{array}{l}\text { Saya sudah } \\
\text { menunggunya } \\
\text { berhari-hari }\end{array} \\
\text { Prefix (ber) + } \\
\text { Noun } \\
\text { (reduplication) }\end{array}$ \\
\hline
\end{tabular}

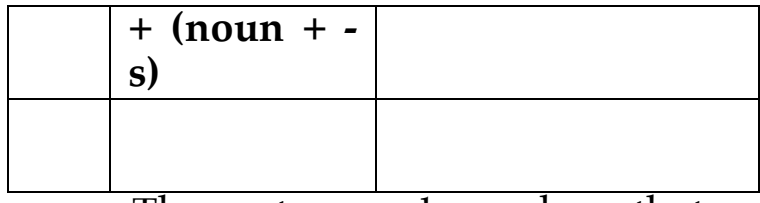

The sentences above show that the plurals of English and Indonesia are different. In English, the plurals are marked by adding the suffix -s, and -es, to the nouns. The -es suffix is added to nouns end in -sh, ch, -ss, and $-x$. whereas the noun ending in $-y$, if the letter before $y$ is a vowel then $-y$ will be -i and added -es as in the example given. The basic word is baby and the plural is babies. Nouns ending in -o, some plural forms are added -es and some are only added -s. If the noun ends in -f or -fe, the plural will be marked by adding -ves as in sentence 8 .

However, in sentence 11, no additional affixes were found in the basic word because this word is an exception. There are a number of nouns that already have their own plural forms and their numbers are also limited which are not found in Indonesian. These words are:

\begin{tabular}{|l|l|}
\hline Singular & Plural \\
\hline Child & Children \\
\hline Foot & Feet \\
\hline Goose & Geese \\
\hline Man & Men \\
\hline Mouse & Mice \\
\hline Tooth & Teeth \\
\hline Woman & Women \\
\hline Person & People \\
\hline
\end{tabular}

The plural forms in English are very different from the Indonesian language, where in Indonesian the plural forms of words are formed by repetition (reduplication) of the nouns themselves as in sentences 2,5 , and 7 . The Indonesian plural forms are also formed by the addition of quantifier and number, such as two, four, many, several, etc. If the number accompanies a noun, so reduplication of the noun is not needed. Conversely, if the noun is not accompanied by a 
number or quantifier, then the noun will be duplicated.

Different with Indonesian, Plurals in English do not need reduplication, but addition of suffix to the noun. The use of numeric words also do not change the plurals.

\section{Difficulties in Learning Plurals}

This difference will certainly cause difficulties for Indonesians in learning the English plural because there are some rules that depend on the noun itself. The plural in English is formed through the process of affixation (addition of affixes) to most nouns, although there are indeed a number of nouns that have their own form in the plural.

Basically, the formation of most plural words in English is through an affixation process, namely the addition of the -s suffix, but there are some words that are added with the -es, and -ies suffixes. There are also some nouns that have their own plural forms without the addition of suffixes, and there are also some words that have the same plural form as the singular.

\section{Lesson plan}

Teaching plural is included in the teaching of language construction, especially in the field of morphology. There are two types of approaches given by Harmer (2007) in teaching language construction, namely:

1. A deductive approach

In this approach, students are given an explanation of the grammar and then create their own example sentences based on the explanation that has been given. Harmer (2007) says that in giving explanations to students, teachers are expected to explain the understanding and construction of the language itself. Examples of methods that use this approach are PPP (presentation, practice production) methods.

2. Inductive approach
Unlike the deductive approach, the inductive approach learns grammar through examples and concludes the grammar language used.

The following will be given a lesson plan that would be used to assist in teaching plural English forms.

This is an example of lesson plan using a deductive approach.

Lesson plan

1. Topic: home sweet home

2. Learning objective: students will be able to create plural nouns and use them in sentences

3. Materials

Flash cards of plurals noun (things at home)

A picture of things at home

4. Lesson procedure

1. Warmer: Match the pictures (things at home)

Teacher distribute a card to each student of either the picture or word of singular and plural nouns. Students match the picture with the word.

2. Teacher makes two columns on the board, singular and plural, and ask them to put their pictures and words on the right column.

3. Teacher describe the rule of plurals to the students.

4. Doing worksheet. Teacher show a picture to students and ask them to write all things that they find from the picture. Example: there is a book, there are four mangoes.

5. Describe their home. Teacher asks each student to make their own description about things at their house.

6. Teacher ask the difficulties in learning about plurals and conclude the meeting.

\section{CONCLUSION}

From the explanation above, it is known that the structure of the plural between English and 
Indonesian is different although some similarities were found. Indonesian learners will find difficulty to learn plural words because in terms of word formation, English and Indonesian are very different. The formation of plural words in English is through the process of affixation, while the formation of words that have plural meaning in Indonesian through the process of reduplication and the addition of numerical words. For this reason, it is necessary to give more explanations and exercises to learn the plural of English because with a lot of practice, it is hoped that Indonesian learners will start to get used to the formation of the plural words.

\section{REFERENCES}

Arifin, Zaenal dan Amran Tasai. 1985. Cermat Berbahasa Indonesia untuk Perguruan Tinggi. Jakarta
Azar, Betty Schrampfer. 2003. Fundamentals of English Grammar. England: Longman

Bawa, dkk. 1989. Bahasa Indonesia di Perguruan Tinggi. Surabaya: Himsa Jaya

Harmer, Jeremy. 2007. The Practice of English Language Teaching. England: Longman

Izzan, Ahmad. 2008. Metodologi Pembelajaran Bahasa Inggris. Bandung: Humaniora

Mukarto, dkk. 2006. English on Sky 1. Jakarta: Erlangga

Tarigan, H.G. 1989. Pengajaran Kompetensi Bahasa Indonesia. Bandung: Angkasa

Tim Penyusun. 1996. Kamus Besar Bahasa Indonesia. Jakarta: Balai Pustaka 